\title{
First record of qualitative losses caused by Meghimatium pictum in vineyards of Southern Brazil and the effects of two molluscicides for its control
}

\author{
Primeiro Registro de perdas qualitativas causadas por Meghimatium pictum em vinhedos \\ do Sul do Brasil e os efeitos de dois moluscicidas para o seu controle
}

\author{
Cléber Antonio Baronio ${ }^{I}$ Marcos Botton ${ }^{\text {II }}$ Suzete Rodrigues Gomes ${ }^{\text {II }}$ \\ David Gwyn Robinson'II
}

\section{ABSTRACT}

This research reports the terrestrial slug Meghimatium pictum (Stoliczka, 1873) (Stylommathophora: Philomycidae) as an agricultural pest for the first time in Southern Brazil vineyards. The species was found in densities exceeding 20 slugs.m ${ }^{-2}$ in Vitis labrusca $L$. vineyards at six municipalities of the Southern Brazil's viticulture region. It causes damage a loss by leaving residual mucus on grapes and by consuming grapes already perforated by other organisms, such as insects or birds, or mechanically damaged by in situ compression. The effectiveness of iron phosphate and metaldehyde baits on $\boldsymbol{M}$. pictum was evaluated in laboratory experiments. Iron phosphate bait was more effective in controlling M. pictum (70\%) than metaldehyde bait (15\%).

Key words: terrestrial slug, grapevine pest, iron phosphate, metaldehyde.

\section{RESUMO}

$O$ presente trabalho relata pela primeira vez a lesma terrestre Meghimatium pictum (Stoliczka, 1873) (Stylommathophora: Philomycidae) como uma praga agrícola causando danos em vinhedos no Sul do Brasil. Esta espécie foi encontrada em densidades superiores a 20 lesmas. $m^{-2}$ danificando uvas da espécie Vitis labrusca L. em seis municípios da região vitícola do Sul do Brasil. O impacto econômico causado por $\mathbf{M}$. pictum está associado ao movimento dos espécimes no dossel da videira e nas uvas, provocando a contaminação residual por muco e o consumo de uvas já perfuradas por outros organismos, tais como insetos ou aves, ou mecanicamente danificadas pela compressão in situ. A eficácia das iscas a base de fosfato de ferro e metaldeído sobre $\boldsymbol{M}$. pictum também foi avaliada em condições de laboratório. A isca a base de fosfato de ferro foi mais eficiente no controle de M. pictum (70\%) do que a isca a base de metaldeído (15\%).

Palavras-chave: lesma terrestre, praga da videira, fosfato de ferro, metaldeído.

\section{INTRODUCTION}

Many terrestrial gastropods species (slugs and snails) are considered major agricultural pests, attacking numerous crops species. The number of pest mollusks has increased during the twentieth century due to the introduction of new crops, intensification of agricultural production and accidental introduction of alien species that have adapted to modify agricultural environments (GODAN, 1983; THOMÉ, 1993; DI STEFANO, 1998; ROBINSON, 1999; BARKER, 2002; BARKER, 2002; COWIE et al., 2009). This has led to an increased focus on agricultural malacology.

Meghimatium pictum (Stoliczka, 1873) (Stylommathophora: Philomycidae) is a terrestrial slug native to China, Taiwan, Malaysia, and probably India (WIKTOR et al., 2000). In recent years it has been reported from southern and southeastern Brazil (GOMES et al., 2011) and northeast Argentina (GREGORIC et al., 2013). According to GOMES et al. (2011), in urban regions of Brazil individuals are usually found in wastelands within peripheral

${ }^{I}$ Departamento de Fitossanidade, Universidade Federal de Pelotas (UFPel), CP 354, 96010-900 Pelotas, RS, Brasil. E-mail: cleber.baronio@hotmail.com. Autor para correspondência.

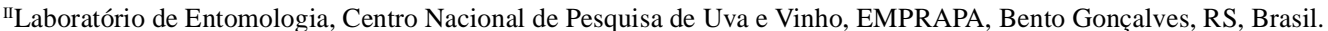

IIINational Malacology Laboratory, United States Department of Agriculture (USDA), Animal and Plant Health Inspection Service (APHIS), Plant Protection and Quarantine (PPQ), National Identification Services (NIS), Academy of Natural Sciences of Drexel University (ANSP), Philadelphia, USA. 
areas under fallen trunks, limbs, stones or garbage. In relatively undisturbed forests, they are found on woody stems, inside hollow trunks or near or under bryophytes. They were generally found in humid and dark places, buried or underneath various objects. Some specimens were found up to $1.5 \mathrm{~m}$ above ground level in Paraná state.

GOMES et al. (2011) recorded M. pictum infesting plants in private kitchen gardens in the state of Santa Catarina and also to invade several protected areas in Paraná. GREGORIC et al. (2013) recorded one specimen of $\boldsymbol{M}$. pictum in a garden with orchids collected from the province of Misiones and other plants acquired from nurseries in the Tucumán province. However, there were no records of serious damage or observable effects on native species so far. This study is the first to report this species as an agricultural pest causing significant economic losses in commercial Vitis labrusca L. vineyards in several municipalities of Rio Grande do Sul in southern Brazil. The effectiveness of baits containing iron phosphate and metaldehyde as control for M. pictum was evaluated under laboratory conditions.

\section{MATERIAL AND METHODS}

Observations of the damage caused by M. pictum were made during visits to vineyards in Antônio Prado, Nova Pádua, Bento Gonçalves, Farroupilha, Garibaldi and Caxias do Sul, in the state of Rio Grande do Sul, Brazil. Levels of infestation were estimated based on the number of specimens. $\mathrm{m}^{-2}$.

For species identification specimens were collected on the field and dissected in the laboratory using a stereomicroscope to enable the evaluation of diagnostic features, as well as comparisons with specialized literature (TSAI et al., 2005; GOMES et al., 2011). Voucher specimens were deposited at the United States Department of Agriculture National Malacology Laboratory collection in Philadelphia (USDA 110437).

To test the effectiveness of an iron phosphate and a metaldehyde bait on $\boldsymbol{M}$. pictum in laboratory experiments, specimens of several sizes were collected in vineyards located in Antônio Prado and stored in $500 \mathrm{~mL}$ plastic containers. Each container was filled with approximately one centimeter of damp soil in order to maintain humidity and replicate the slug's natural environment, thus avoiding dehydration. Temperature and relative air humidity were constant during bioassays $\left(25 \pm 1^{\circ} \mathrm{C}\right.$ and $55 \pm 5 \%$, respectively), with a photophase of 14h. The following treatments were used: T1 - 0.5g Metarex $\mathrm{SP}^{\circledR}$ (5\% a.i. metaldehyde) - De Sangosse Agroquímica Ltda manufacturer; T2 - 0.5g Ferramol $^{\circledR}$ (1\% a.i. iron phosphate) - W. Neudorff Serviços de Agricultura do Brasil Ltda manufacturer (BIO CONTROLE, 2011); and T3 - control. The experimental design was completely randomized with six replicates (plastic containers) that included five slugs each. Both baits used a starch-based attractive ingredient. Specimens were selected and distributed in order to obtain similar sizes for each replicate. Containers with one gram of cattle feed (crushed and roasted corn and soybeans) were added to all treatments and replicates as alternative food sources. All replicates were evaluated after 24, 48, 72, 96, 120, 144 and 168 HAI (Hours After Installation). The bait was considered effective if it attracted and killed the slugs. Treatment averages were compared by the Tukey test with a 5\% error probability rate $(\mathrm{P}<0.05)$, using the SAS ${ }^{\circledR}$ software (SAS INSTITUTE, 2000).

\section{RESULTS}

An analysis of the reproductive system and external characteristics confirmed the species as M. pictum. The species was recorded to cause losses during the harvest season of Niagara and Bordô grapevines ( $\boldsymbol{V}$. labrusca) in Antônio Prado, Nova Pádua, Bento Gonçalves, Farroupilha, Garibaldi and Caxias do Sul. Qualitative loss caused by $\boldsymbol{M}$. pictum has been observed over the past three years, mainly during grape harvesting season (December to March), and also during the grape production period in the municipalities of Antônio Prado and Garibaldi. The slugs feed on the pulp of fruit that are pre-damaged by other organisms, such as insects and birds, or on grapes mechanically damaged by hail or compression (Figure $1 \mathrm{~A}-\mathrm{B}$ ). Also, they leave trails of secretion while moving towards and across grape clusters. They are mainly active at night but also during daytime after rainfall.

At daytime they were found under stones, wood and the ground-cover of dead vegetation, often used in the Southern Brazil's vineyards (Figure 1 D). Cover crops gradually release nutrients as they decay, protecting the soil against erosion and stabilize its temperature and humidity. These protectional layers are generally made from cut or naturaly crop residues of vetch, oats, rye grass and clover after harvesting. A trellis system is used that provides constant shading in the interior of the vineyard, to prevent solar radiation from reaching most of the soil surface (Figure $1 \mathrm{C}$ ). These areas showed higher levels of infestation. In an area of 4.3 hectares in Caxias do 

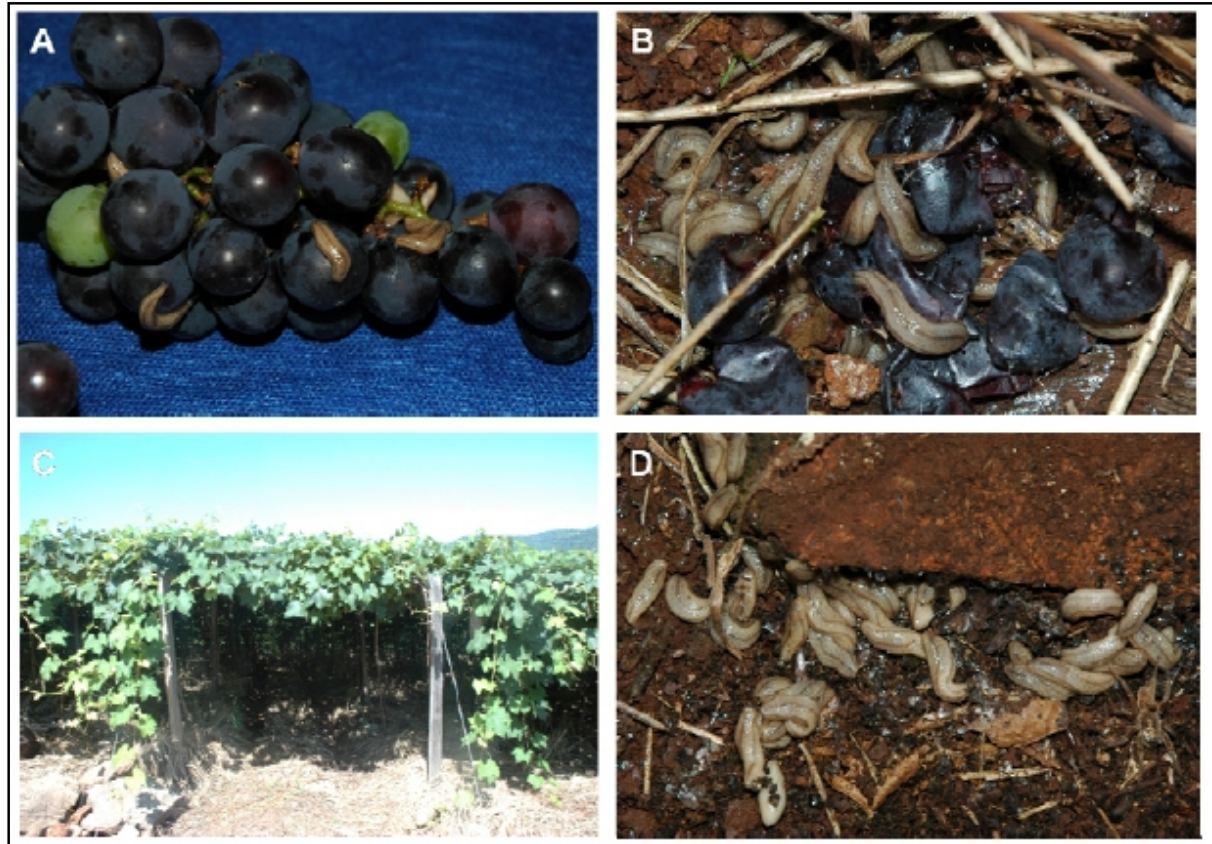

Figure 1 - Slugs feeding on grapes (A-B) and examples of environments within grapevines were slugs are found (C-D), in Bento Gonçalves, Rio Grande do Sul, Brazil.

Sul, average slug density reached 20 individuals. $\mathrm{m}^{-2}$. In a smaller area in Antônio Prado, with less mulch on the soil surface and poor vegetation cover, lower densities were found with an approximate average of five specimens. $\mathrm{m}^{-2}$. Slugs were also found in storage boxes used during harvest, mainly in boxes kept in the vineyards overnight.

Specimens were not attracted to metaldehyde bait after $24 \mathrm{HAI}$, and mainly consumed the alternative food source of cattle feed. This did not change during subsequent evaluations for this treatment. Iron phosphate baits were highly attractive to specimens and were consumed entirely, suggesting that snails preferred this bait to the alternative food source. In the first two evaluations, at 24 and 48 HAI, none of the two treatments was lethal to $\boldsymbol{M}$. pictum. At 72 HAI mortality rates of $6.7 \%$ and $13.3 \%$ were observed for metaldehyde and iron phosphate treatments, respectively (Figure 2).

After 120 HAI the mortality rate in the iron phosphate treatment was $53.3 \%$, whereas the metaldehyde treatment did not effectively control slugs, with a mortality rate of only $10 \%$ (Figure 2). In the final evaluation, at $168 \mathrm{HAI}$, the mortality rate in the metaldehyde treatment (Metarex $\mathrm{SP}^{\circledR}$ ) remained below $15 \%$, but increased to $70 \%$ in the iron phosphate treatment $\left(\right.$ Ferramol $\left.^{\circledR}\right)$ which proved to control M. pictum more effectively.

\section{DISCUSSION}

This is the first record of $\boldsymbol{M}$. pictum as an agricultural pest, damaging agricultural crops in Southern Brazil. Infestation causes losses that significantly affect vineyards in the region with the largest Brazilian grape producers for in natura consumption, processed juice and vinification. Grapevine cultures cover approximately 82,000 ha in Brazil, mostly in the States of Santa Catarina, Paraná and Rio Grande do Sul, the latter being the main grape growing area for processed products (MELLO, 2011). GODAN (1983) recorded two species of slugs as grapevines pests: Deroceras reticulatum (Müller, 1774) and Deroceras agreste (Linnaeus, 1758) (Agriolimacidae) and four species of snails: Cepaea hortensis (Müller, 1774), Cepaea memoralis (Linnaeus, 1758), Helix aspersa (Müller, 1774) (= Cornu aspersum) and Helix pomatia (Linnaeus, 1758) (Helicidae). More recently, CHANG (2002) also recorded Bradybaena similaris (Férussac, 1822) (Bradybaenidae) to attack vines in Taiwan. SANDERSON \& SIRGEL (2002) mention that the introduced helicids Cantareus aspersus (Müller, 1774) (= Cornu aspersum) and Theba pisana (Müller, 1774) (Helicidae) can also reach pest status in South African viticultural regions. All these families are members of the order Stylommathophora (THOMÉ et al., 2006). 


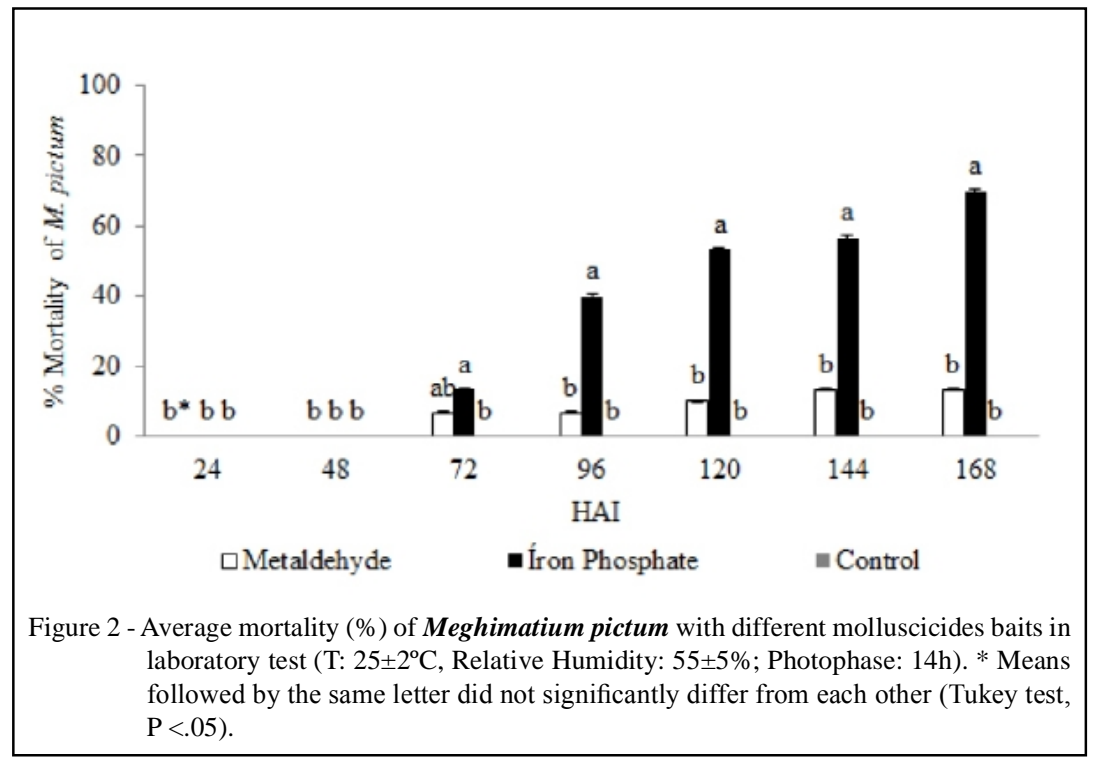

The presence of $\boldsymbol{M}$. pictum impairs in natura grape sales, as well as the quality of wine and juice. The slugs cause losses by feeding on previously perforated or damaged grapes, leaving residual mucus, which affects consumer acceptance. American agricultural inspectors have found this species mainly on mushrooms shipments from China (GOMES et al., 2011). It is possible that slugs are initially attracted by the natural yeast on grape surfaces. SANDERSON \& SIRGEL (2002) mention that the juveniles of $\boldsymbol{C}$. aspersum and T. pisana feed on developing foliage during spring. Additionally, during humid evenings in spring and early summer, active slugs leave mucus trails on developing grapes, impacting their aesthetic appearance and rendering table grapes unsuitable for export markets.

Injury caused by $\boldsymbol{M}$. pictum usually occurs during the grape harvest period between December and March, although some qualitative loss could be detected during the production period as well (Garibaldi). According to CHANG (2002), $\boldsymbol{B}$. similaris can destroy leaf and buds, and may also be responsible for defoliation (especially of new leaves), flower and fruit spoilage. Similar to M. pictum, numbers and feeding activities of this species on the vines are higher in the warmest and wettest months (May to September) (CHANG, 1988) and during the vines' growth and fruiting period. The level of infestation was higher in areas with cover crops inside vineyards that provide perfect humidity and shading conditions in an environment with high food availability. According to SANDERSON \& SIRGEL (2002) mollusks infestations on vines primarily occur when gastropod populations on the ground are disturbed by vineyard management practices, such as ground cover cultivation or mowing.. They also comment that during the late 1980s there was a significant increase in the emergence of gastropods as viticultural pests in Australia, associated with changes in soil-management practices, especially tillage reductions, improved irrigation and use of ground-cover and mulches.

The iron phosphate (T2) baits were not lethal to mollusks during the two first evaluations ( 24 and $48 \mathrm{HAI}$ ). This may be related to the mode of action of the active ingredients: iron phosphate acts as a feeding inhibitor, making slugs slower, hardening their epidermis, and leading to death in three to six days after ingestion (IGLESIAS \& SPEISER, 2001; SPEISER \& KISTLER, 2002; MENDES, 2008). Similarly, the metaldehyde was not lethal for slugs in the first 24 hours, although metaldehyde causes rapid dehydration in mollusks. Low consumption might have influenced mortality. Metaldehyde baits were the mainstay of terrestrial gastropod chemical control before the introduction of carbamate-based baits in the 1950s. However, the application of these two types of molluscicides results in environmental problems, since both are toxic for vertebrates (HOMEIDA \& COOKE, 1982; FLETCHER et al., 1991, 1994). The need to apply higher doses of these products (from 20 to $40 \mathrm{~kg} \cdot$ ha $^{-1}$ baits in a single year) also makes their use impracticable on open fields (CHIARADIA, 2001; QUINTELA, 2002). Although more expensive, iron phosphate (Ferramol ${ }^{\circledR}$, Neudorff GmbH, Germany) is a new control option less aggressive and toxic to 
the environment (EPA, 2011) and is used in many European countries (SPEISER et al., 2001).

Attractiveness of molluscicide baits and control potential for different species may vary depending on the active ingredient and the age of the mollusks (GODAN, 1983; PORT \& PORT, 1986; RAE et al., 2009). RAE et al. (2009) observed that baits containing iron phosphate were efficient in controlling two slug species in Ukraine (D. reticulatum and Arion ater (Linnaeus, 1758) (Stylommathophora: Arionidae)). They also verified that the efficacy of baits containing iron phosphate was not different from treatments with baits containing metaldehyde over the course of the experiment. The results of their study indicate that adult $\boldsymbol{A}$. ater specimens can be successfully controlled by recommended doses of both molluscicides. Evaluating the protective effect of baits containing iron phosphate and metaldehyde, RAE et al. (2009) found that both products provide a high protection level for Chinese cabbage saplings against $\boldsymbol{A}$. ater and $\boldsymbol{D}$. reticulatum. Baits containing iron phosphate reduced lettuce damage, but were less efficient than baits containing metaldehyde (SPEISER \& KISTLER, 2002).

\section{CONCLUSION}

This paper reports $\boldsymbol{M}$. pictum as an emerging new pest in Southern Brazil's vineyards and present evidence that the use of baits containing iron phosphate can be an alternative to control this pest, killing $70 \%$ of the specimens 168 hours after its application under laboratory conditions.

\section{REFERENCES}

BARKER, G. M. Molluses as Crop Pests. CABI Publishing, Wallingford, 2002, 450p.

BIO CONTROLE. Ferramol. Available in: <http://www. biocontrole.com.br>. Access in November 30, 2011

CHANG, C. P. The occurrence and control of Bradybaena similaris (Férussac). Bulletin of Taichung District Agricultural Improvement Station, v.21, n.1, p.1-2, 1988

CHANG, C. Bradybaena similaris (de Férussac) (Bradybaenidae) as a pest in grapevines of Taiwan. In.: BARKER, G.M. (Ed.). Molluscs as crop pests. CABI Publishing, Wallingford, 2002, p.241-245.

CHIARADIA, L. A. Avaliação de iscas moluscicidas no controle de Sarasinula linguaeformis (Semper, 1885). In.: Reunião Técnica Catarinense de Milho e Feijão. Epagri, Chapecó, 2001. p.71-75.

COWIE, R. H. et al. Alien non-marine snails and slugs of priority quarantine importance in the United States: A preliminary risk assessment. American Malacological Bulletin, v.27, n.1-2, p.113-132, 2009. Available in: <http://www.bioone.org/doi/ pdf/10.4003/006.027.0210>. Access in: July 26 ${ }^{\text {th }}, 2012$. doi: 10.4003/006.027.0210.

DI STEFANO, J. G. Lesmas no plantio direto no cerrado. Direto no Cerrado, v.7, p.8-9, 1998.

ENVIRONMENTAL PROTECTION AGENCY (EPA). Iron (ferric) phosphate. Office of Pesticides Program fact sheet. Available in: <http://www.epa.gov/pesticides/biopesticides/ ingredients/factsheets/factsheet_034903.htm>. Access in: May $23^{\text {rd }}, 2011$.

FLETCHER, M. R. et al. Pesticide Poisoning of Animals 1990 London, MAFF Publications, 1991, 30p.

FLetCHer, M. R. et al. Pesticide Poisoning of Animals 1993. London, MAFF Publications, 1994, 52p.

GODAN, D. Pest slugs and snails. Biology and Control. New York, Springer-Verlag, 1983, 445p.

GOMES, S. R. et al. A newly introduced and invasive land slug in Brazil: Meghimatium pictum (Gastropoda, Philomycidae) from China. Proceedings of the Academy of Natural Sciences of Philadelphia, v.161, n.1, p.87-95, 2011. Available in: <http:// www.bioone.org/doi/abs/10.1635/053.161.0106>. Access in: July $13^{\text {rd }}, 2012$. doi: $10.1635 / 053.161 .0106$.

GREGORIC, D. E. G. et al. First Record of four exotic slugs in Argentina. American Malagological Bulletin, v.31, n.2, p.1-12, 2013.

HOMEIDA, A. M.; COOKE, R. G. Pharmacological aspects of metaldehyde poisoning in mice. Journal of Veterinary Pharmacology and Therapeutics, v.5, n. 1, p.77-82, 1982. Available in: <http://onlinelibrary.wiley.com/doi/10.1111/j.1365-2885.1982. tb00500.x/abstract>. Access in: July $17^{\text {th }}$, 2012. doi: 10.1111 / j.1365-2885.1982.tb00500.x.

IGLESIAS, J.; SPEISER, B. Consumption rate and susceptibility to parasitic nematodes and chemical molluscicides of the pest slugs Arion hortensis s. s. and A. distinctus. Anzeiger fuer Schaedlingskund, v.74, n.6, p.159-166, 2001. Available in <http:// onlinelibrary.wiley.com/doi/10.1046/j.1439-0280.2001.d01-5.x/ pdf $>$. Access in: July 22 ${ }^{\text {nd }}, 2012$. doi: $10.1046 / j .1439-0280.2001$. d01-5.x.

MELLO, L. M. R. DE. Vitivinicultura Brasileira: Panorama 2010. Artigos Técnicos. EMBRAPA/CNPUV, Bento Gonçalves, 2011. Available in: <http://www.cnpuv.embrapa.br/publica/artigos/ prodvit2010[1].pdf>. Access in March 21, 2011.

MENDES, A. G. Controle de lesmas e caracóis. Revista Cultivar, v.47, p.14, 2008 .

PORT, C. M.; PORT, G. The biology and behavior of slugs in relation to crop damage and control. Agricultural Zoology Reviews, v.1, p.255-299, 1986.

QUINTELA, E. D. Manejo de Lesmas. Revista Cultivar, v.38, p.26-28, 2002.

RAE, R. G. et al. Optimization of biological (Phasmarhabditis hermaphrodita) and chemical (iron phosphate and metaldehyde) 
slug control. Crop Protection, v.28, n.9, p.765-773, 2009. Available in: <http://www.sciencedirect.com/science/article/pii/ S0261219409000969>. Access in: May 21 ${ }^{\text {st }}$ 2012. doi: 10.1016/j. cropro.2009.04.005.

ROBINSON, D. G. Alien invasions: The effects of the global economy on non-marine gastropod introductions into the United States. Malacologia, v.41, n.2, p.413-438, 1999.

SANDERSON, G.; SIRGEL, W. Helicidae as pests in Australian and South African grapevines. p. 255-270. In.: BARKER G. M. (Ed.). Molluscs as crop pests. Wallingford, CABI Publishing, 2002. 450 p.

SAS INSTITUTE. Statistical Analysis System: getting started with the SAS learning. Cary, SAS Institute Inc., 2000. 81p.

SPEISER, B.; KISTLER, C. Field tests with a molluscicide containing iron phosphate. Crop Protection, v.21, n.5, p.389394, 2002. Available in: <http://www.sciencedirect.com/science/ article/pii/S0261219409000969\#>. Access in: May 21 ${ }^{\text {st }}$, 2012. doi: 10.1016/j.bbr.2011.03.031.
SPEISER, B. et al. Size-specific susceptibility of the pest slugs Deroceras reticulatum and Arion lusitanicus to the nematode biocontrol agent Phasmarhabditis hermaphrodita. Biocontrol, v.46, n.3, p.311-320, 2001

THOMÉ, J. W. Estado atual da sistemática dos Veronicellidae (Mollusca; Gastropoda) americanos, com comentários sobre sua importância econômica, ambiental e na saúde. Biociências, v.1, n.1, p.61-75, 1993. Available in: <http://www.scielo.br/pdf/rbzool/ v18n1/v18n1a34.pdf>. Access in: May 21 ${ }^{\text {st }}$, 2012, doi: 10.1590/ S0101-81752001000100034.

THOMÉ. J. W. et al. Os caracóis e as lesmas dos nossos bosques e jardins. Pelotas: USEB, 2006. 123p.

TSAI, C. L. et al. Comparison of four philomycid slugs (Gastropoda: Stylommatophora: Philomycidae) of Taiwan. Endemic Species Research, v.7, p.41-49, 2005.

WIKTOR, A. et al. Stylommatophoran slugs from China (Gastropoda: Pulmonata). Prodromus. Folia Malacologica, v.8, n.1, p.3-35, 2000. 